\title{
Sonographic finding of the bright thalamus
}

\author{
E Y SHEN, C C HUANG, S C CHYOU, H Y HUNG, C H HSU, AND F Y HUANG \\ Department of Pediatrics, Mackay Memorial Hospital, Taipei, Taiwan
}

SUMMARY Six of 83 asphyxiated neonates showed a diffuse increase of echodensity in bilateral thalami with or without other lesions in the basal ganglia on sonographic examination. The thalamic image still had a fairly high echogenecity compared with the surrounding brain parenchyma on follow up examination and was hence termed the bright thalamus. These six patients had a poor neurological outcome, including psychomotor retardation, spastic diplegia or quadriplegia, microcephaly, failure to thrive, seizures, and one death. The bright thalamus is not an occasional or an isolated sonographic finding of hypoxic-ischaemic encephalopathy, but it may serve as a landmark of severe hypoxic brain damage with adverse outcome.

Neonatal asphyxia is one of the main problems occurring in neonatal intensive care units. Brain insult during the neonatal period accounts for the adverse neurological outcome in many handicapped children with non-progressive neurological deficits. ${ }^{1}$ The introduction of sector sonography provides an efficient, non-invasive diagnostic technique to evaluate these asphyxiated neonates at the bedside, even if the subject is being mechanically ventilated. The sonographic findings of post-asphyxial encephalopathy have been described by several authors. ${ }^{2-4}$ An additional finding of hyperechodense bilateral thalami has been reported by one of us. ${ }^{5}$ This finding had been termed the 'bright thalamus'. To clarify this finding and its prognostic value, the sonographic features of six cases with bright thalamus are presented and their clinical features as well as short term outcome are described.

\section{Patients and methods}

Eighty three patients with fetal distress or perinatal asphyxia were admitted to the neonatal intensive care units of our hospital from October 1983 to September 1985. All of them received sonographic examination of the brain either once or sequentially over an indefinite period. Perinatal asphyxia was defined according to the criteria of Mulliga et al and Finer et $a l^{6}{ }^{7}$ Timing of the examination was decided by the attending physician according to the clinical state of the patient. The sonographic scanning was performed by the physician subspecialised in paediatric neurology and brain sonography. Since the first report of high amplitude echogenecity of bilateral thalami in our unit, ${ }^{5}$ we have paid much more attention to the thalamic image obtained by sonography of asphyxiated neonates. Thus we have collected six cases with this finding in the past two years. We present here the study of these cases with their clinical manifestations, sonographic findings, results of computed tomography, and short term outcome.

Brain sonography was performed with the Aloka SSD-720 5.0 MHz sector scanner in both coronal and sagittal plane through the anterior fontanelle approach.

Computed tomograms were obtained in five cases, using a Toshiba TCT $80 \mathrm{~A}$ and scan times of $2 \cdot 7$ seconds.

\section{Results}

The summary of clinical information and computed tomogram and sonographic findings of the six cases with bright thalamus are presented in the Table. All of the subjects were born at term with profound perinatal asphyxia. The delay of initial crying ranged from 10 to 20 minutes, with a mean of $16 \cdot 3$ minutes.

All six cases showed clinical features of hypoxicischaemic encephalopathy with seizures, disturbance of level of consciousness, and hypotonia or hypertonia during the neonatal period.

Timing of detection of the bright thalamus varied from 4 days to 4 months. One case, who had had serial scanning follow up since birth, had a bright thalamus image detected at 89 hours of age. 
Table 1 Summary of clinical, sonographic, and computed tomogram findings of six cases with the bright thalamus

\begin{tabular}{|c|c|c|c|c|c|c|c|}
\hline $\begin{array}{l}\text { Case } \\
\text { No }\end{array}$ & Sex & $\begin{array}{l}\text { Birth } \\
\text { weight }(g)\end{array}$ & $\begin{array}{l}\text { Gesta- } \\
\text { tional age } \\
\text { (weeks) }\end{array}$ & $\begin{array}{l}\text { Clinical } \\
\text { presentation }\end{array}$ & $\begin{array}{l}\text { Sonographic findings } \\
\text { (age at findings) }\end{array}$ & $\begin{array}{l}\text { Computed tomogram } \\
\text { findings } \\
\text { (age at findings) }\end{array}$ & Outcome (age) \\
\hline 1 & $\mathbf{M}$ & 3400 & 40 & $\begin{array}{l}\text { DOIC } 15 \text { min; seizure; } \\
\text { hypotonia; SIADH }\end{array}$ & $\begin{array}{l}\text { High echogenetic } \\
\text { thalami; basal } \\
\text { ganglia (15d: } 3.5 \mathrm{~m})\end{array}$ & $\begin{array}{l}\text { Dilatation of lateral } \\
\text { ventricles and basal } \\
\text { cisterna; isodense } \\
\text { thalami }(25 \mathrm{~d})\end{array}$ & $\begin{array}{l}\text { Psychomotor retardation: } \\
\text { microcephaly; spastic } \\
\text { diplegia }(13 \mathrm{~m})\end{array}$ \\
\hline 2 & $\mathbf{F}$ & 2350 & 40 & $\begin{array}{l}\text { Fetal distress; meconium } \\
\text { stain; DOIC } 20 \text { min; } \\
\text { hypertonia; opisthotonos }\end{array}$ & $\begin{array}{l}\text { Ventricular dilatation; } \\
\text { high echogenetic } \\
\text { thalami }(4 \mathrm{~m} ; 5.5 \mathrm{~m} ; 7.5 \mathrm{~m})\end{array}$ & $\begin{array}{l}\text { Ventricular dilatation; } \\
\text { slightly hyperdense } \\
\text { thalami }(5.5 \mathrm{~m})\end{array}$ & $\begin{array}{l}\text { Seizure; spastic quadriplegia; } \\
\text { microcephaly }(18 \mathrm{~m})\end{array}$ \\
\hline 3 & $\mathbf{F}$ & 3400 & 42 & $\begin{array}{l}\text { Meconium aspiration; } \\
\text { DOIC } 15 \text { min; seizure; } \\
\text { hypertonia }\end{array}$ & $\begin{array}{l}\text { High echogenetic thalami; } \\
\text { basal ganglia }(3 \mathrm{~d} ; 7 \mathrm{~m})\end{array}$ & $\begin{array}{l}\text { Brain oedema; slightly } \\
\text { hypodense thalami }(7 \mathrm{~d})\end{array}$ & $\begin{array}{l}\text { Microcephaly; infantile } \\
\text { spasm }(10 \mathrm{~m})\end{array}$ \\
\hline 4 & $\mathbf{M}$ & 3900 & 40 & $\begin{array}{l}\text { DOIC } 15 \text { min; seizure; } \\
\text { hypertonia; acute } \\
\text { renal failure }\end{array}$ & $\begin{array}{l}\text { Brain oedema; high } \\
\text { echogenetic thalami } \\
\text { (89 h, } 1 \mathrm{~h} \text { after death) }\end{array}$ & - & Died (8d) \\
\hline 5 & F & 1960 & 38 & $\begin{array}{l}\text { DOIC } 15 \text { min; seizure; } \\
\text { hypotonia }\end{array}$ & $\begin{array}{l}\text { High echogenetic } \\
\text { thalami; basal } \\
\text { ganglia }(3 \mathrm{~m} ; 6 \mathrm{~m})\end{array}$ & $\begin{array}{l}\text { Multiple infarction, } \\
\text { involving basal } \\
\text { ganglia, thalami, and } \\
\text { periventricular white } \\
\text { matter }(6 \mathrm{~m})\end{array}$ & $\begin{array}{l}\text { Failure to thrive; } \\
\text { psychomotor retardation; } \\
\text { infantile spasm }(8 \mathrm{~m})\end{array}$ \\
\hline 6 & $\mathbf{F}$ & 3500 & 41 & $\begin{array}{l}\text { Fetal distress, meconium } \\
\text { stain; DOIC } 18 \mathrm{~min} ; \\
\text { seizure; hypotonia; } \\
\text { SIADH }\end{array}$ & $\begin{array}{l}\text { High echogenetic } \\
\text { thalami; } \\
\text { periventricular } \\
\text { hyperechodense }(7 \mathrm{~d} ; 1 \mathrm{~m}) \\
\text { High echogenetic thalami; } \\
\text { multicystic leucomalacia } \\
(3 \mathrm{~m} ; 4 \mathrm{~m})\end{array}$ & $\begin{array}{l}\text { Periventricular } \\
\text { leucomalacia; } \\
\text { slightly hyperdense } \\
\text { thalami }(1 \mathrm{~m})\end{array}$ & $\begin{array}{l}\text { Psychomotor retardation; } \\
\text { microcephaly; spastic } \\
\text { quadriplegia; infantile } \\
\text { spasm }(4 \mathrm{~m} ; 8 \mathrm{~m})\end{array}$ \\
\hline
\end{tabular}

DOIC $=$ Delay of initial crying; SIADH=syndrome of inappropriate antidiuretic hormone secretion.

He died at the age of 8 days. The sonography was performed again one hour after death and showed mild obliteration of the hyperechoes. Unfortunately, we failed to obtain permission for autopsy from the parents. The other five cases received sonography follow up and showed persistence of hyperdense thalamus at the age of $3,3,31 / 2,6$, and 7 months, respectively (Fig. 1).

Computed tomography was performed in the five remaining cases within 10 days after sonographic examination and all showed isodense or slightly hyper- or hypodense thalami (Fig. 2).
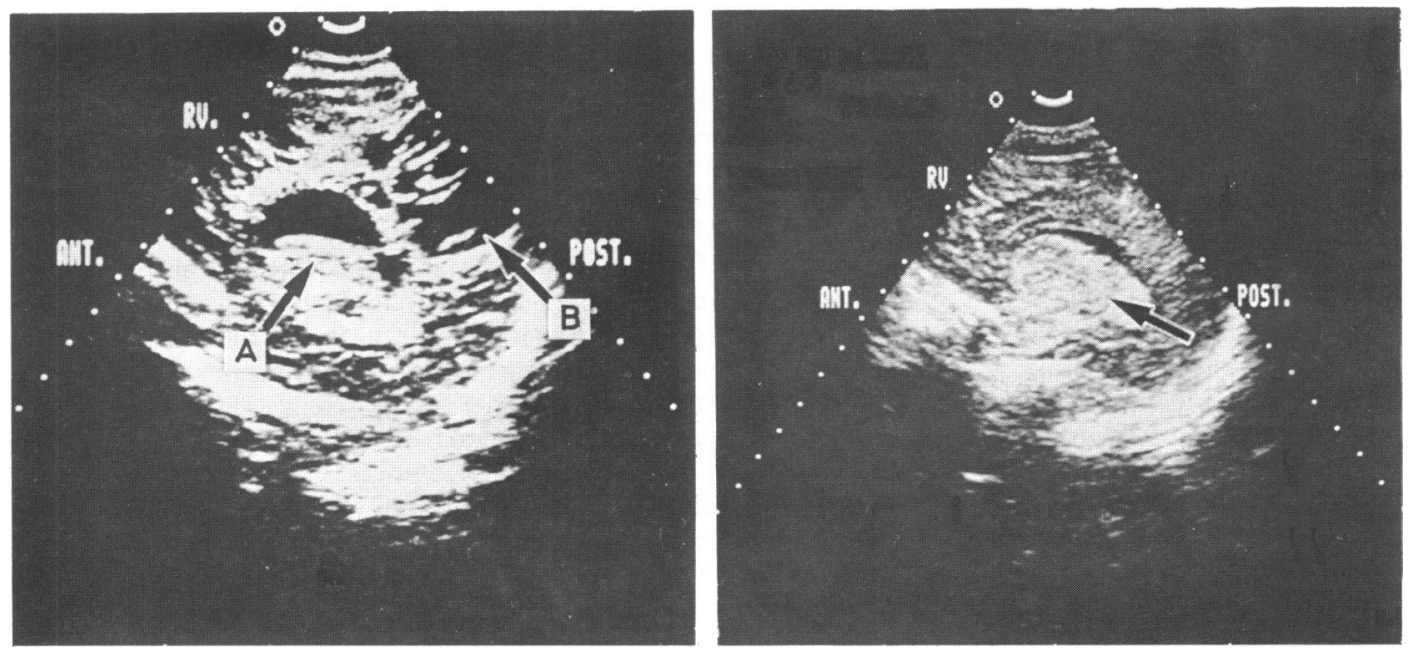

Fig. 1 The bright thalamus. (a) Increased echogenecity of thalamus $(A)$ associated with multicystic periventricular leucomalacia $(B)$. (b) Diffuse echogenecity of thalamus and caudate nucleus (arrow). 

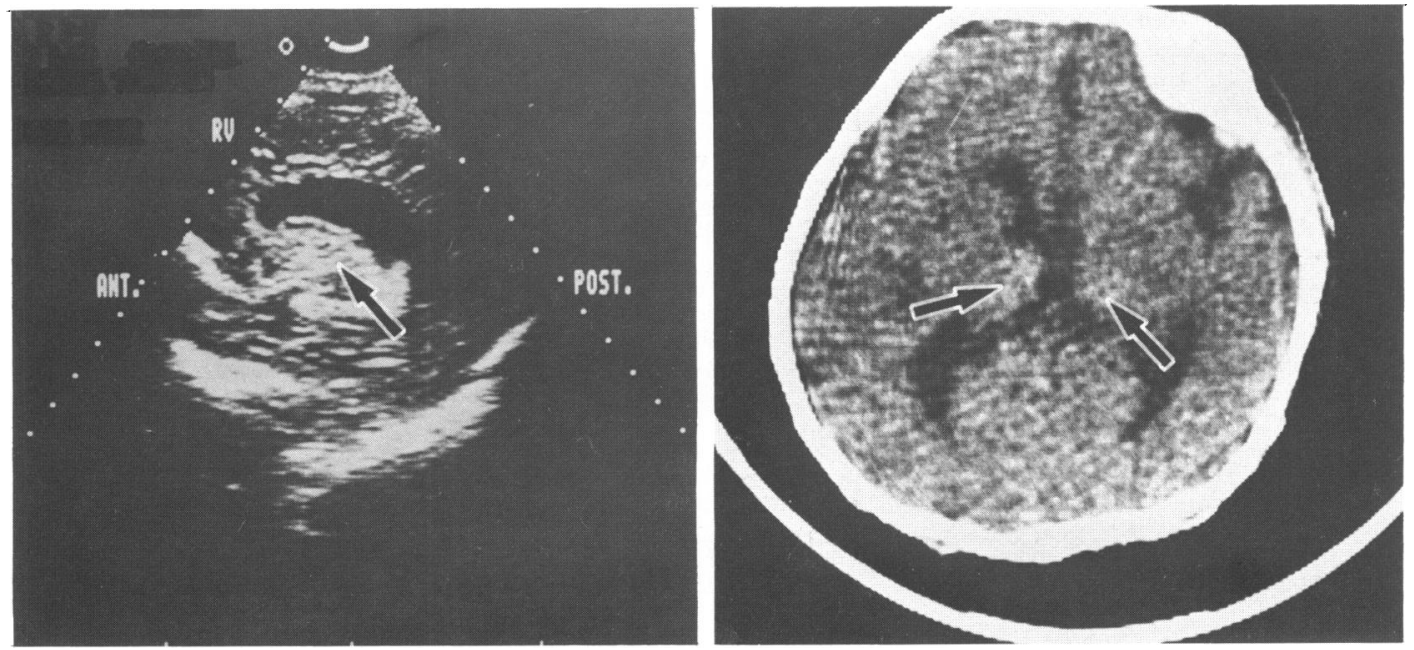

Fig. 2 Case 2. (a) High echogenecity of the bright thalamus in the angle sagittal plane at the age of 51/2 months (arrow). (b) Computed tomogram performed at the same time, showing slight hyperdensity of the thalami (arrow).

\section{Discussion}

In normal sonography of the neonatal brain the thalamus appears as areas of medium level echogenecity. ${ }^{8-10}$ The present study showed a diffuse increase of echogenecity over bilateral thalami in severely asphyxiated infants, and this image persisted on follow up sonography if the patient survived. We believe this may be a pathological feature of hypoxic-ischaemic encephalopathy because it was not found in our previous experience when examining 500 normal Chinese neonates, ${ }^{11} 210$ premature Chinese neonates (when attempting to determine the incidence of subependymal/intraventricular haemorrhage in premature Chinese infants. Unpublished data.), and more than 1200 scans of sick infants who were not asphyxiated.

Previous investigators have succeeded in detecting parenchymal echogenecity in the neonatal brain with post-asphyxial encephalopathy. ${ }^{2-4}$ They suggested that the hyperechogenecity was presumably due to widespread ischaemic change, cerebral oedema, or focal ischaemia in the distribution of one of the major cerebral vessels. ${ }^{4}$

Skeffington et al reported 13 cases of perinatal asphyxia with diffuse high amplitude echogenecity throughout the brain and suggested cerebral oedema. ${ }^{12}$ Others have described an echogenic appearance that corresponded to brain oedema during an intraoperative procedure. ${ }^{13} 14$

In the present six cases two who had been given a sonographic examination in the early neonatal period showed diffuse increase of echogenecity in whole brain parenchyma and obscured the echoes of normal structures as described by Skeffington et al. ${ }^{12}$ The high amplitude echoes attenuated with time, but the thalamic echoes gradually became more obvious. The computed tomograms remained isodense or slightly hypodense compared with other brain parenchyma (Fig. 2). They became slightly hyperdense if the scanning was performed in late infancy.

Primary thalamic haemorrhage is a rare finding during the neonatal period. ${ }^{15-17}$ It may mimic the bright thalamus sonographically. An early computed tomogram may differentiate the bright thalamus from the thalamic haemorrhage by the higher resolution density on the scan of the haemorrhage. From the sonographic point of view, the bright thalamus showed a diffuse homogenous echogenecity all over the thalamus and the margin was sharp and regular. A previous report of acute haemorrhagic necrosis of the thalamus and basal ganglia with neuropathological confirmation showed the striking feature of haemorrhage with strong echogenecity and irregularity of the echoic margin. ${ }^{15}$ The primary thalamic haemorrhage reported by Trounce et al also showed heterogenous echoes of the haemorrhage. ${ }^{16}$ The bright thalamus tends to be a diffuse parenchymal change of the thalamus rather than a focal destructive lesion.

Hypoxic-ischaemic insults may cause diffuse brain damage, in particular to the cerebral cortex, subcortical and periventricular white matter, basal ganglia, 
brain stem, and cerebellum. ${ }^{18} 19$ The thalamus is one of the nervous tissues most vulnerable to hypoxia. Sensory nuclei, including the thalamus, lateral geniculate body, and colliculi, are the subcortical structures that bear the brunt of asphyxic brain damage because of their high metabolic requirement. ${ }^{18}$ Rorke suggested that selective damage to thalamus or deep grey nuclei, or both, probably results from diminution of blood flow in branches of basal penetrating vessels or from the phenomenon of selective neuronal vulnerability. ${ }^{19}$

Sonographically, the bright thalamus was just one feature of hypoxic-ischaemic encephalopathy in our cases. Increased echoes of the basal ganglia (cases 1,3, and 5) and parenchymal change, such as multicystic periventricular leucomalacia (case 6), were also noted. Whether there is any lesion in the brain stem or cerebellum is difficult to ascertain due to the limited resolution of the machine. The outstanding thalamic echogenecity is, however, much more easily identified than others. Thus it may represent a critical sign of hypoxic brain insult.

The neuropathology of the persistence of the bright thalamus in late infancy remains obscure. We presume this could be a feature of status marmoratus and look forward to a pathological confirmation. This disorder is more common in term than in premature infants, with premature birth being noted in fewer than $5 \%$ of cases. ${ }^{21} 21$ The neurological manifestations of status marmoratus in the neonatal period are unknown. ${ }^{1}$ A further study of the correlation between the bright thalamus and status marmoratus will be helpful in identifying this disorder early.

Five of our cases survived and all showed pronounced psychomotor retardation and other complications, such as microcephaly, seizures, spastic diplegia or quadriplegia, and failure to thrive. The thalamic damage per se may not account for all of these complications. From the present study, we found that only $7 \%(6 / 83)$ of the asphyxiated neonates had such complications, and all of them had longer duration of asphyxia than others. This suggests that the bright thalamus is only found in profoundly asphyxiated neonates.

In summary, the bright thalamus should be distinguished from thalamic haemorrhage or other thalamic desease. It is not an occasional or an isolated finding in hypoxic-ischaemic encephalopathy. The association of increased echogenecity of the basal ganglia or other parts of the brain is not rare. But because of its easy identification, we suggest that the bright thalamus may serve as a landmark of profound asphyxic brain damage with adverse neurological outcome.
We thank the sisters and nursing staff of the neonatal intensive care units for their help and cooperation and Miss $\mathrm{H} \mathrm{J}$ Chang for technical help.

\section{References}

' Volpe JJ. Neurology of the newborn. Philadelphia: W B Saunders, 1981.

${ }^{2}$ Hill A, Martin DJ, Daneman A, Fitz CR. Focal ischemic cerebral injury in the newborn: diagnosis by ultrasound and correlation with computed tomographic scan. Pediatrics 1983;71:790-3.

${ }^{3}$ Babcock DS, Ball W. Post asphyxial encephalopathy in full-term infants: ultrasound diagnosis. Radiology 1983;148:417-23.

${ }^{4}$ Siegel MJ, Shackelford GD, Perlman JM, Fulling KH. Hypoxicischemic encephalopathy in term infants: diagnosis and prognosis evaluated by ultrasound. Radiology 1984;152:395-9.

5 Shen EY. The 'bright thalamus'. Arch Dis Child 1984;59:695.

6 Mulliga JC, Painter MJ, O'Donoghue PA, MacDonald HM, Allen AC, Taylor PM. Neonatal asphyxia. II. Neonatal mortality and long-term sequela. J Pediatr 1980;96:903-7.

7 Finer NN, Robertson CM, Richards RT, Pinnen LE, Peters KL. Hypoxic-ischemic encephalopathy in term neonates: perinatal factors and outcome. J Pediatr 1981:98:112-7.

${ }^{8}$ Kossoff G, Garrett WJ, Radovanovich G. Ultrasonic atlas of normal brain of infant. Ultrasound Med Biol 1974;1:259-66.

${ }^{9}$ Pigadas A, Thompson JR, Grube GL. Normal infant brain anatomy: correlated real-time sonograms and brain specimens. AJR 1979;137:815-20.

10 Shuman WP, Rogers JV, Mack LA, Alvord EC, Christie DP. Real-time sonographic sector scanning of the neonatal cranium: technique and normal anatomy. $A J R$ 1981;137:821-8.

1 Shen EY, Huang FY. Subependymal cysts in normal neonates. Arch Dis Child 1985;60:1072-4.

12 Skeffington FS, Pearse RG. The 'bright brain'. Arch Dis Child 1983;58:509-11.

13 Smith SJ, Vogelzang RL, Marzano MI, Cerullo LJ, Gore RM, Neiman HL. Brain edema: ultrasound examination. Radiology 1985;155:379-82.

14 Williams JL. Intracranial vascular pulsations in pediatric neurosonology. Journal of Ultrasound Medicine 1983;2:485-8.

15 Kreusser KL, Schmidt RE, Shackelford GP, Volpe JJ. Value of ultrasound for identification of acute hemorrhagic necrosis of thalamus and basal ganglia in an asphyxiated term infant. Ann Neurol 1984;16:361-3.

16 Trounce JQ, Fawer CL, Punt J, Dodd KL, Fielder AR, Levene MI. Primary thalamic haemorrhage in the newborn: a new clinical entity. Lancet $1985 ; \mathrm{i}: 190-2$.

17 Kotagal S, Toce SS, Kotagal P, Archer CR. Symmetric bithalamic and striatal hemorrhage following perinatal hypoxia in a term infant. J Comput Assist Tomogr 1983;7:353-5.

18 Vannucci RC, Voorhies TM. Perinatal cerebral hypoxiaischemia: pathogenesis and neuropathology. In: Sarnat HB, ed. Topics in neonatal neurology. Orlando: Grune and Stratton, 1984:27-59.

19 Rorke LB. Pathology of perinatal brain injury. New York: Raven Press, 1982.

20 Friede RL. Developmental neuropathology. New York: Springer-Verlag, 1975:64-75.

${ }^{21}$ Malamud N. Status marmoratus: a form of cerebral palsy following either birth injury or inflammation of the central nervous system. J Pediatr 1950;37:610-9.

Correspondence to Dr E Y Shen, Mackay Memorial Hospital, 92, Section 2, Chung-San N Road, Taipei, Taiwan, Republic of China.

Received 1 July 1986 